\title{
CONSIDERATIONS REGARDING THE EVOLUTION OF THE SOLIDIFIED CRUST AT THE CONTINUOUS CASTING STEEL
}

\author{
Marian BORDEI \\ "Dunarea de Jos" University of Galati, Romania \\ e-mail: mbordei@ugal.ro
}

\begin{abstract}
The continuous casting of the steel can cause cracks on the surface or inside, which arise due to thermal and mechanical stresses. To eliminate these defects, mathematical models are drawn up with which temperature fields, expansions and stresses can be determined. The purpose of making these models is to locate the areas with a high risk of cracking so that, finally, the continuous casting machines and working conditions can be modified, so as to eliminate, or at least diminish, the defects. The knowledge of the thermal state of the steel in the continuous casting machine is necessary for the transposition on mathematical bases of the technological process and the elaboration of some simulation models of the solidification, which would allow the optimization of the afferent plant.

The proposed mathematical model takes into account - when studying the heat transfer phenomena in the tundish - the convective motion of the steel, which influences the thickness of the solidified crust and the evolution of the temperature in the section of the continuously cast steel thread.

By running the simulation program were determined the variation of the thickness of the solidified crust as a function of time, overheating in the crystallizer and convection coefficient.
\end{abstract}

KEYWORDS: continuous casting, thermal state, solidification crust

\section{Introduction}

The process of continuous casting of semifinished products is characterized by a number of parameters that condition both the design and construction of specific installations-machineryequipment, as well as the quality of the products on the flow-casting. In addition to the "classic" processes, more and more efficient manufacturing processes are constantly appearing: casting thin slabs, casting with the deformation of the steel wire in the machine or casting.

The most important difficulties - which must be overcome when adopting such technologies - can be grouped into:

- casting of semi-finished products with minimum defects;

- conservation of thermal energy for the purpose of direct rolling;

- reduction of the thickness of the semi-finished products with or without deformation in the continuous casting installation (with the correlation of their components);
- adaptation of the rolling to the new conditions: direct deformation (with the minimum decrease of the temperature between casting and deformation), reduced corrosion to rolling, etc.

To study the thermal state of continuous cast steel thread, empirical models can be used - obtained by correlating experimental value results with mathematical simulation models. In general, empirical models cannot be extrapolated to conditions other than those for which the experiments were performed, when some parameters (temperature of the steel inside the thread, thickness of the solidified crust, etc.) are difficult to follow. Mathematical models have the advantage that, once verified, they have generalization possibilities.

Kohn and Morillon studied the solidification of steel taking into account the heat exchanges by convection in liquid steel; for this, they considered that the liquid consists in of two media, one corresponding to the dendritic solidification zone - in which the heat exchanges are made by conduction and the second one - corresponding to the equiaxial solidification zone, the convective displacement of the liquid leading to a constant temperature [1]. 
Tozoshima and Takasashi proposed a model for "semi-solid" materials, by applying Darcy's law to the movement of liquid steel through interdendritic spaces - in the case of the biphasic solid-liquid zone [2].

Miyazawa developed a mathematical model for estimating the solidification profile and slab surface temperature, using the integration of the continuous cast thread section and took into account the different effects of cooling rate and cooling conditions on the upper and lower slabs, respectively.

Although the number of continuous casting machines has increased a lot, however, the complex processes regarding the solidification and cooling of the related semi-finished products are still in the research phase, not being elaborated a unitary model, generally valid for the respective processes.

Taking into account the presented aspects, we proposed a mathematical model for determining the evolution of the crust solidification and heat flux in the tundish, as well as a model for determining the temperature in the continuously cast steel thread - on the path to the exit of the machine.

The alloy used for the research is a generalpurpose carbon steel for construction S235J2G4, according to EURONORM 10025 (OL 37-4k, according to STAS 500). The thermophysical parameters of steel solidification were calculated according to studies and research in the literature [3].

\section{Theoretical considerations on the convection phenomenon at the solid-liquid interface}

The thermal state of liquid steel is characterized by overheating (the difference between the temperature of the steel at a given time - at a given level - and the temperature of the liquid). It is important to know, at different levels of the machine, the thickness of the solidified crust and the temperature distribution in the liquid steel, as well as the temperature of the liquid steel as the solidification front advances.

At the solid-liquid interface (at the boundary of the solidification front) a convection heat transfer takes place. The existence of convective motion can lead to a reduction in the thickness of the solidified crust at the respective level in the tundish, as well as to a significant increase in the temperature on the surface of the product, at the exit of the tundish. For these reasons, it is necessary to take into account the convective motion when studying the heat transfer phenomena in the tundish.

To solve this problem, mathematical analysis solutions can be used for the case of free border systems. The model must allow the numerical evaluation of the thermal state of the steel, in accordance with the experimental results that can be obtained at a certain level of the tundish, during an industrial casting. In order to reduce the perforations, a sufficiently thick and uniform solid crust must be ensured at the exit of the tundish.

\section{Results obtained}

Based on the mathematical relationships in the literature, the variation of the solidified crust of continuously cast steel was determined [5]. By running the program, the variations of the thermophysical parameters depending on the temperature characteristic of the studied steel were determined (Figures 1-4), respectively, the variation of the thickness of the solidified crust as a function of time.

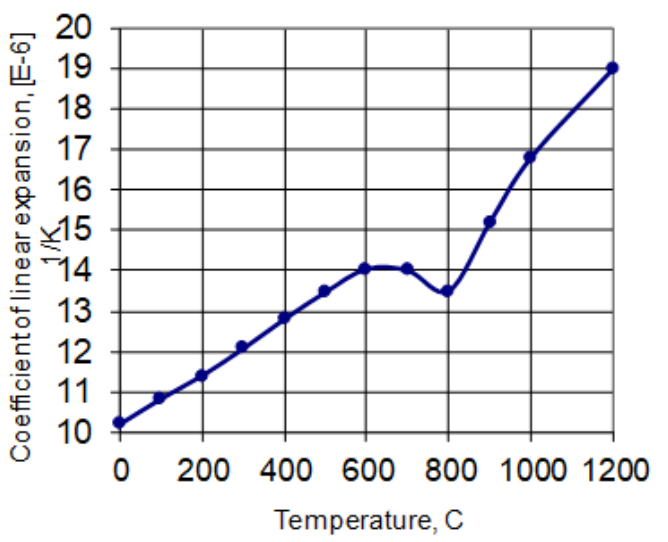

Fig. 1. Variation of the coefficient of linear expansion of steel as a function of temperature

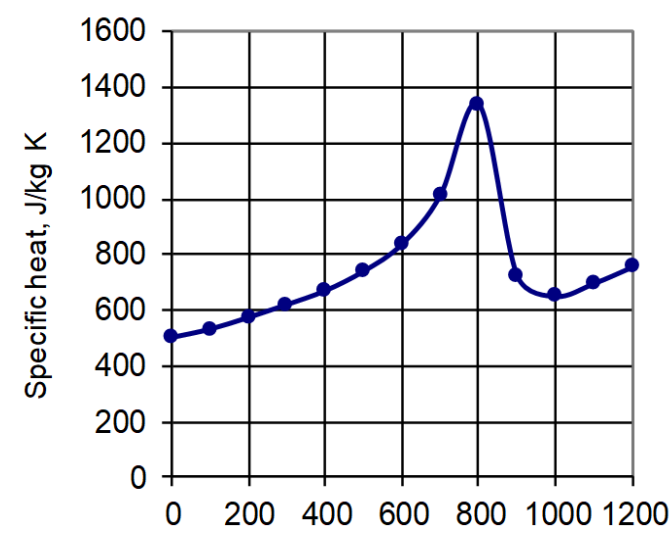

Temperature, $\mathrm{C}$

Fig. 2. Variation of specific heat of steel as a function of temperature 


\section{THE ANNALS OF "DUNAREA DE JOS" UNIVERSITY OF GALATI \\ FASCICLE IX. METALLURGY AND MATERIALS SCIENCE \\ No. 4 - 2020, ISSN 2668-4748; e-ISSN 2668-4756 \\ Article DOI: https://doi.org/10.35219/mms.2020.4.04}

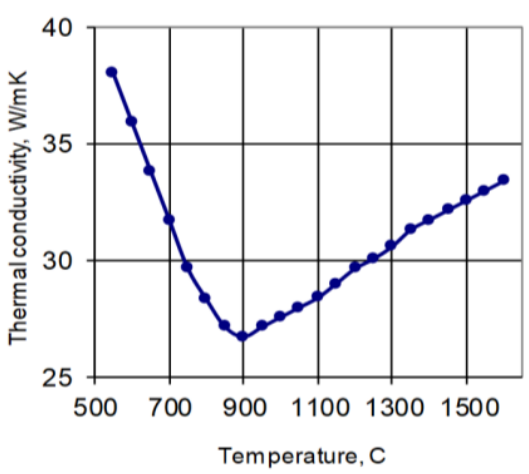

Fig. 3. Variation of thermal conductivity of steel as a function of temperature

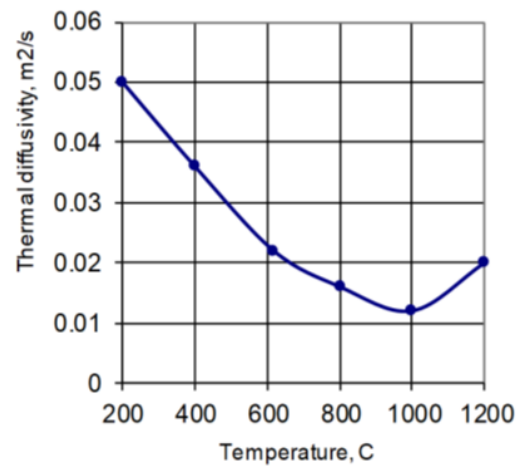

Fig. 4. Variation of the thermal diffusivity coefficient of the steel as a function of temperature

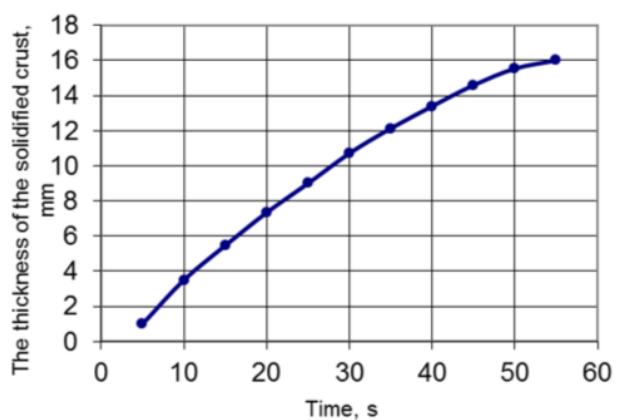

Fig. 5. Variation of the crust thickness solidified over time

\section{Conclusions}

Following the analysis of the diagrams obtained by calculation with the mathematical model used, some conclusions can be drawn that contribute to the understanding of the phenomena that take place in the tundish and to the optimization of the parameters of the solidification process of the continuously cast slabs.

The thickness of the solidified crust increases along the path in the tundish - being favored by the following factors:

- the lower the overheating is;

- with the decrease of the convection coefficient;

- with the decrease of the casting speed.

\section{References}

[1]. ***, Continuous Casting, vol. 1-9, Iron and Steel Society, 186 Thorn Hill Road, Warrendale, PA 15086-7512, 1979-1997.

[2]. ***, Modeling of Casting and Welding Processes, Conference Series, vols. 1-10, TMS, Warrendale, PA.

[3]. ***, Continuous Casting, in the Making, Shaping, and Treating of Steel, vol. 2, A. Cramb, ed. Pittsburgh, PA: Assoc. of Iron \& Steel Engineers, 2003.

[4]. Oprea S., Corelaţia dintre proprietăţile termofizice si mecanice ale materialelor metalice cu procesul de incălzire, Metalurgia, p. 435-445, 7/1973.

[5]. Bordei M., Considerente privind deformarea plastica a semifabricatelor turnate continuu in scopul optimizarii unor parametri ai proceselor de turnare continua-laminare, Teză de doctorat, Galati, 1999.

[6]. Bratu V., Mortici C., Oros C., Ghiban N., Mathematical model of solidification process in steel continuous casting taking into account the convective heat transfer at liquid-solid interface, Computational Materials Science, vol. 94, November 2014.

[7]. Rogberg B., Testing and Application of a Computer Program for Simulating the Solidification Process of a Continuous Cast Strand, Teză de doctorat, Stockholm, 1990.

[8]. Bamberger M., Mathematical model for the solidification of high-carbon steel in continuos casting, Iron and Steel International, 2/1977.

[9]. Barber B., Détermination de la température de surface sur ligne de coulée continue et du transfert thermique lors de la coulée continue, La Revue de Métallurgie-CIT, 11/1996.

[10]. Bordei M., Cercetări privind îmbunătățirea randamentului de metal prin creşterea calităţii tablelor şi benzilor obţinute prin laminarea bramelor turnate continuu, Contract nr. 67/1996, beneficiar: SIDEX S.A Galați. 